\title{
HISTÓRIA ORAL NA PANDEMIA: IDOSOS EM SITUAÇÃO DE ISOLAMENTO SOCIAL NARRATIVA AUTOBIOGRÁFICA DE OLYMPIA ÁVILA SALSA.
}

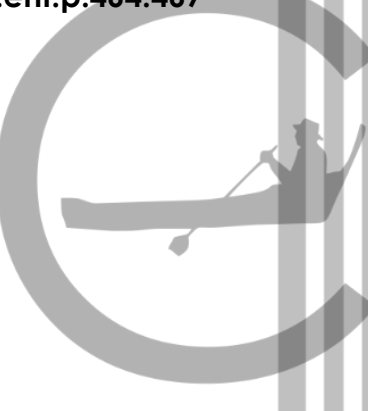

Juniele Rabêlo de Almeida*

O acervo "História Oral na Pandemia" é composto por narrativas públicas, autobiográficas, de idosos com vida social ativa - em situação de isolamento social frente aos desafios do novo COVID 19. Trata-se de trajetórias de vida que expressam, qualitativamente, os impactos sociais da pandemia sobre esse grupo vulnerável. Tais narrativas (gravadas em áudio e enviadas para um portal público - storage do Laboratório de História Oral e Imagem da Universidade Federal Fluminense - Labhoi/UFF) são entrevistas (história oral de vida) a partir de uma escuta sensível das experiências em espaço virtual aberto (domínio público); os idosos assumem os desafios e as perspectivas de se narrar aspectos de seu cotidiano no contexto da pandemia.

O objetivo é promover políticas públicas atentas as demandas sociais dos idosos, pois o acervo integra o grande projeto "A Covid-19 no Brasil”" (MCTIC) ${ }^{1}$, com quatro núcleos de pesquisa distribuídos nos principais estados do país com uma equipe multidisciplinar de aproximadamente 60 pessoas. Compreende-se, a partir do acervo, que a população idosa tem sido destacadamente visada como população de risco. Busca-se, assim, analisar a produção discursiva (narrativas, sentidos, concepções, valores) sobre a pandemia e subsidiar proposições de políticas públicas.

O acervo de entrevistas públicas, acolhido pelo Labhoi/UFF, é composto por narrativas gravadas e transcritas - que apontam para a necessidade da valorização das trajetórias e das experiências cotidianas dos idosos. O material presta-se também à observação das estratégias narrativas desses sujeitos, que repensam publicamente suas trajetórias nesses tempos desafiadores. Motivados pela pergunta "Como está o seu cotidiano nesses tempos de covid19?”, recebemos breves gravações de áudio sobre o

\footnotetext{
* Professora da Universidade Federal Fluminense (UFF). Doutora em História pela Universidade de São Paulo (USP). Pesquisadora do Labhoi/UFF e uma das coordenadoras do projeto História Oral na Pandemia. ${ }^{1}$ Projeto "A COVID-19 no Brasil: Análise e resposta aos impactos sociais da pandemia entre profissionais de saúde e população em isolamento" (Ministério da Ciência, Tecnologia e Inovações / MCTIC Coordenação-Geral de Ciências Humanas e Sociais Aplicadas: UFRGS; Fiocruz Minas).
} 
cotidiano nesses "tempos de pandemia". Solicitamos, juntamente com o arquivo da gravação. o nome completo do colaborador, data da gravação, cidade/país, ano e local de nascimento. Para fornecer o direito de divulgar a narrativa de história oral os entrevistados autorizaram sua utilização para fins sociais e educativos. A construção do acervo segue as seguintes etapas: divulgação da chamada para o acervo, recebimento das narrativas enviadas; cadastro dos materiais no acervo; transcrição e edição do material.

O objetivo é envolver populações de idosos, com vida social ativa, na produção de autobiografias - memória social no tempo presente diante das restrições de circulação (impacto da situação de isolamento nas suas práticas de sociabilidade). Para tanto se propõe a análise da produção narrativa desses idosos sobre a o contexto da pandemia; subsidiando políticas públicas que ultrapassem os dados estatísticos e assumam, qualitativamente, as vozes em primeira pessoa - diante das desigualdades sociais reverberadas na pandemia.

Após ampla divulgação do projeto recebemos várias narrativas. Dentre elas a narrativa autobiográfica da professora de Artes, já aposentada, Olympia Ávila Salsa encaminhada para o nosso acervo no dia 22 de maio de 2020. Olympia, generosamente, aceitou o desafio autobiográfico: dissertar, o mais livremente possível, sobre sua experiência pessoal, segundo sua vontade e condições. Com sensibilidade e compromisso social, se mostrou uma narradora engajada. Sua história entrecruzou reflexões sobre pandemia e desigualdades sociais.

Olympia Ávila Salsa se apresentou e buscou contextualizar os desafios da pandemia. Vale observar as suas escolhas narrativas no processo de significação da sua trajetória na pandemia. Apresentamos, a seguir, uma edição da narrativa autobiográfica da professora Olympia.

\section{Narrativa autobiográfica de Olympia Ávila Salsa}

\section{“Triste nesse período é não saber o que nos espera. Como será o dia seguinte?"}

Eu me chamo Olympia Avila Salsa. Nasci em 16 de fevereiro de 1949 na cidade do Rio de Janeiro. Moro em São Gonçalo e sou viúva. Tenho dois filhos, um é morador em Niterói e o outro no Rio. Moro sozinha, mas tenho duas companheiras, uma cachorrinha que adotei, a Milu, e uma gatinha, a Flora. Uma semana antes de começar o isolamento social, estive com meus filhos. Era o aniversário de 50 anos do meu mais velho, fizemos 
uma festinha para receber os amigos. Brindamos, nos abraçamos, mas a partir desse dia eu não vi mais ninguém. Não vi mais meus filhos, netas e nora. Assim achei melhor para minha segurança. Faço tudo em casa, cozinho e faço compras uma vez por semana no comércio local que fica pertinho de casa. Tomo todos os cuidados.

Durante esses dias da pandemia tenho me sentido bem de saúde. Mas vivo preocupada, me observando, para ter a certeza de que estou bem mesmo... E que não sinto nada fora do normal. Nenhum sintoma! O dia mais triste foi o dia das mães... Eu não pude abraçar os meus filhos! Fiquei sem internet e isso me impediu de ver mais tarde a live que minha nora e meu filho iriam fazer. Mas, no final, deu tudo certo. Eles cantaram uma música de autoria dele em minha homenagem. Eu me emocionei muito! Não esquecerei mais esse dia.

Tenho motivos de preocupação, sim! Muitas vezes me sinto impotente e até me revolto com notícias que vejo na tv. Falta de honestidade, desumanidade, irresponsabilidade. Porém, não me deixo abalar não! Sou espírita e me apego ao estudo da doutrina e das orações. Procuro preencher meu tempo com atividades físicas, meditação, pintura e os cuidados com a casa.

Sou professora de artes aposentada por invalidez porque tive um câncer de mama há quatro anos. Preciso, uma vez por mês, ir à ONCORIO para acompanhamento. Faço tratamento com uma injeção de hormônio e, por isso, tive que ir ao Rio fazer alguns exames. Eu me senti muito insegura; por ter que me expor a riscos.

Sou aluna da formação de bonança e, com isso, compreendi melhor a vida e o que vem acontecendo comigo e com todos. Busco me orientar em meio à pandemia, e busco os melhores aprendizados para que, quando tudo tiver passado, poder acompanhar as mudanças.

Triste nesse período é não saber o que nos espera. Como será o dia seguinte? E o futuro? O que irá acontecer? Principalmente por não termos segurança por parte dos governos. O que mais me incomoda, e é muito revoltante até, é ver o número de pessoas que morrem por irresponsabilidade dos gestores. Somos marionetes em suas mãos.

Tenho o suficiente para viver, mas quando penso nos menos favorecidos, me dá muita pena por não poder ajudá-los! Sou grupo de risco e não poderia atuar tão próximo. E, financeiramente, não tenho condições nesse momento... Espero que não falte nada pra mim mais lá na frente, pois sei que o país está vivendo momentos difíceis devido à corrupção que aqui se instalou e se perpetua. Temos que aprender com tudo isso.

Tive que conter minha ansiedade... Pra que a pressa? Agora, tenho todo o tempo do 
mundo! Posso fazer tudo o que eu desejar! Se não fizer num dia, faço no outro. E vamos vivendo um dia de cada vez. Tudo vai passar. 